\title{
REVIEW
}

\section{Sports medicine training in Turkey}

\author{
H Yaman
}

BrJ Sports Med 2002;36:258-259

Sports medicine training in Turkey is reviewed. The current level of training is outlined and a curriculum needs assessment made. The main problems in athletic health care are discussed and solutions suggested. Changes in education, financing, and policy are recommended.
Correspondence to:

H Yaman' Süleyman

Demirel University, Medical

Faculty, Isparta, Turkey

Correspondence to:

Dr Yaman, Celebiler mh

119, Cd no $11 / 7,32040$

Isparta, Turkey:

hyaman@sdu.edu.tr

Accepted 26 March 2002

....................
T he specialty of sports medicine is inadequately developed in Turkey. The scientific approach to sport dates back to the beginning of the 20th century. Specialist training in sports medicine began in the 1970s, and even today sports medicine struggles to be recognised by the other medical specialties in Turkey.

Turkey has a population of 63 million. The proportion of young people is high, and over ten million are in education. ${ }^{1}$ Over 150000 athletes are registered with 37 different sports federations recognised by the General Directory of Sports and Youth in Turkey. A total of 5560 clubs offer different sporting opportunities. The most popular sports are soccer, basketball, athletics, wrestling, and martial arts. ${ }^{2}$

Medical care for elite athletes is provided by one of three athletic education and health centres run by the General Directory of Sports and Youth or by the sports medicine departments of university medical schools. Physical examination before participation can be obtained at any health institution, but standardisation of such examinations is lacking.

\section{UNDERGRADUATE MEDICAL EDUCATION IN TURKEY}

M edical education has a long tradition in Turkey dating back to the middle of the 19th century. After the second world war, there evolved an affinity for founding new medical schools and increasing the number of doctors. The number of medical schools had increased to 47 by the year 2000. Medical education is mostly provided by governmental faculties. Education in medical schools is oriented to primary care. Students have to compete for entrance to these schools after grade 11 (age 16-17). Students with the top 5\% of results from a central higher education examination have access to this privileged medical education. ${ }^{3}$ Medical training in Turkey lasts six years and follows a standard curriculum. After finishing medical education, graduates have two choices for career devel opment: to work as a general medical officer in primary care in rural areas or attend further specialist training. Places for residencies are few, and only about $5 \%$ of applicants are successful.

\section{POSTGRADUATE EDUCATION (RESIDENCY TRAINING) IN SPORTS MEDICINE}

The first sports medicine residency was established in 1973. It lasted two years and consisted of 11 courses relevant to sports medicine. Five specialists in sports medicine graduated from this programme between 1973 and 1981. ${ }^{4}$ Between 1981 and 1989 only orthopaedic surgeons, physiatrists, and physiologists were al lowed to attend a sports medicine training programme. In 1989 the Turkish M inistry of Health accepted sports medicine as a medical specialty and increased the length of training to 3 years. The number of courses was reduced to four (table 1)..$^{5}$ On completion of the three year course and passing the examination, the graduates are awarded the title of specialist in sports medicine by the M inistry of Health. Furthermore, the opportunity to subspecialise for one year in sports medicine was given to orthopaedic surgeons and physiologists by this legislation.

The number of sports medicine departments at medical schools has increased to 15 over the last 10 years. Only these departments are allowed to give postgraduate education in sports medicine. Three to five residency places are offered a year.

The current curriculum aims to produce graduates who are proficient in the management of common health problems and rehabilitation and to providetimely emergency interventions for injured athletes. Because of the general dissatisfaction with the curriculum, ${ }^{6}$ the Turkish Society of Sports Physicians and the Coordination Council of M edical Specialty Societies are preparing a new draft curriculum, in which the training is increased to four years and newer courses relevant to sports medicine are added (table 2). The duration of fellowships for orthopaedic surgeons and physiatrists has been increased to two years. ${ }^{5}$

Graduates from these sports medicine residencies are forced to work in unrelated fields because of the lack of an appropriate infrastructure. Some of them choose an academic career in universities whereas others choose to work in private health institutions, health centres run by the General Directory of Sports and Youth, or with sport teams.

Table 1 Course schedule of sports medicine residency training in Turkey

\begin{tabular}{ll}
\hline Course & Duration \\
\hline Sports medicine & 20 months \\
Cardiology & 6 months \\
Orthopaedics & 10 months \\
Physical medicine and rehabilitation & 6 months \\
\hline
\end{tabular}


Table 2 Suggested course schedule for sports medicine specialisation (Society of Turkish Sports Physicians)

\begin{tabular}{ll}
\hline Course & Duration \\
\hline Sports medicine & 26 months \\
Cardiology & 4 months \\
Orthopaedics & 6 months \\
Physiology & 6 months \\
Physical medicine and rehabilitation & 6 months \\
\hline
\end{tabular}

\section{FUTURE OF SPORTS MEDICINE IN TURKEY}

Around 39.9 million (65\%) of the population are covered by health insurance, whereas about 21.4 million (35\%) are not. ${ }^{7}$ Free sports medical support is provided only for elite athletes. Amateur athletes have to cover their own health expenditures. Therefore athletes with sport specific health problems do not routinely receive care from a competent, sports medicine oriented institution, and a standard physical examination before participation is often lacking.

The need for doctors specialising in sports medicine is therefore still great. A major problem is the lack of specialist and career posts for specialist in sports medicine.

The Turkish Society of Sports Physicians has been trying to promote the highest standards in the specialty since its foundation in 1965. It has published the Turkish J ournal of Sports Medicine, which is one of the oldest journals in Turkey, since 1966 and organises a national sports medicine congress every two years.

The character of sports medicine has changed over the last few years from a purely doctor based discipline to a multidisciplinary structure. More and more professionals such as physi otherapists, nutritionists, and psychologists are involved. Over 50 schools of physical education and kinesiology also contribute graduates to sports medicine. At institutes for health sciences, master of science and doctor of philosophy degrees in sports medicine can be achieved.

I believe that despite these positive changes in sports medicine, considerable changes and improvements in the health

\section{Take home message}

The specialty of sports medicine is ina dequately developed in Turkey. This could be rectified by creating new specialist and career posts in sports medicine, improving the postgraduate curriculum in sports medicine, providing health insurance for all athletes, integrating sports medicine courses into the undergraduate curriculum, and educating the population about the advantages of specially trained sports doctors.

care system for athletes must be made. Health insurance for all athletes should be provided. New specialist and career posts and well equipped centres should be provided for doctors willing to care for athletes. An urgent need is the integration of sports medicine courses into undergraduate medical education, because most graduates will go on to work in rural areas, where they will often deal with sports injuries. The abilities of sports doctors need to be advertised to the population as a whole, especially sports clubs and organisations, to achieve a well recognised sports medicine discipline in Turkey.

\section{REFERENCES}

1 Hamzaoglu O, Kilinç B. Turkish health statistics 2000. (In Turkish.) Ankara: Turkish Medical Association, 2000.

2 The General Directory of Sports and Youth. Statistics of the General Directory of Sports and Youth. (In Turkish.) http:/ / www.izmir.gsim.gov.tr Accessed 100 ct 2001.

3 Sayek I, Kiliç B. Undergraduate medical education report, 2000. (In Turkish.) Ankara: Turkish M edical Association, 2001.

4 Ergen E. Sports and medicine. (In Turkish.) In: Ergen E, ed. Sports medicine lectures. Ankara: Turkish M edical Association Publishing, 1992:3-10.

5 The Coordination Committee of Medical Specialty Societies. Suggestions for curriculum changes in postgraduate medical education 2001. (In Turkish.) http:/ / www.ttb.org.tr. Accessed 110 ct 2001.

6 Yaman $\mathrm{H}$, Ö zen M. Satisfaction with family medicine training in Turkey: a survey of residents. Croatian Medical Journal 2002;43:54-7.

7 Hayran O, Karavus M, A ksayan S. Help-seeking behavior and self-medication of a population in an urban area in Turkey: cross sectional study. Croatian Medical Journal 2000;41:327-32.

\section{Call for peer reviewers}

Clinical Evidence is a regularly updated evidence based journal available world wide both as a paper version and on the internet. Clinical Evidence urgently needs to recruit a number of new contributors. Contributors a re health care professionals or epidemiologists with experience in evidence based medicine and the ability to write in a concise and structured way.

Clinical Evidence needs to recruit a number of new peer reviewers. Peer review ers are health care professionals or epidemiologists with experience in evidence based medicine. As a peer reviewer you would be asked for your views on the clinical relevance, validity and accessibility of specific topics within the journal, and their usefulness to the intended audience (international generalists and health care professionals, possibly with limited statistical knowledge). Topics are usually 2000-3000 words in length and we would ask you to review between $2-5$ topics per year. The peer review process takes place throughout the year, and our turnaround time for each review is ideally 10-14 days.

If you are interested in becoming a peer review er for Clinical Evidence, please complete the peer review questionnaire at www.clinicalevidence.com or contact Polly Brown (pbrown@bmjgroup.com). 